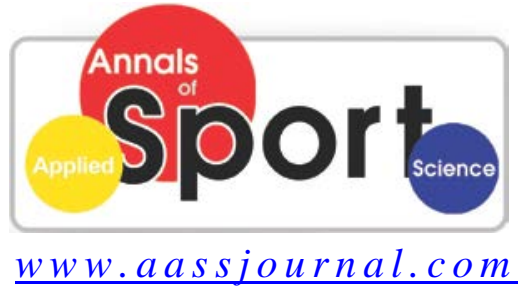

ISSN (Online): 2322 - 4479

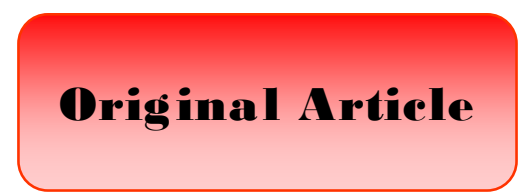

Received: 31/03/2015

Accepted: 23/07/2015

\title{
Knowledge, Attitude and Practices Regarding Muscular Reinforcement among Judokas in Developing Countries: Case Study of the Republic of Benin
}

\author{
${ }^{1}$ Polycarpe Gouthon*, ${ }^{1}$ Jean-Paul Kouassi, ${ }^{2}$ Kouame N'Guessan, \\ ${ }^{1}$ Issiako Bio-Nigan, ${ }^{1}$ Brigitte Tonon, ${ }^{1}$ Basile Nouatin, ${ }^{1}$ Léonce Linta, \\ ${ }^{3}$ Jean-Marie Falola, ${ }^{3}$ Barnabé Akplogan
}

1. Laboratory PSA and Motricity, National Institute of Youth, Physical Education and Sport (INJEPS), University of Abomey-Calavi, Porto-Novo, Republic of Benin.

2. Laboratory of Biology, Motricity, Sports Performance, Sports Medicine and Prevention, National Institute of Youth and Sports, Abidjan, Republic of Côte d'Ivoire.

3. Laboratory Biomechanics and Performance (LABIOP), National Institute of Youth, Physical Education and Sport (INJEPS), University of Abomey-Calavi, Porto-Novo, Republic of Benin.

\section{BSTRACT}

This cross-sectional survey determined the level of knowledge, attitude, and practice about muscular reinforcement (MR) among judokas in the Republic of Benin as typical of a developing country. It also examined the relations between the levels of knowledge, attitude, and practice among these judokas. It was undertaken using a non-probabilistic and exhaustive sample of 79 judokas in the cities of Cotonou and Porto-Novo having a minimum rank of green belt. The levels of knowledge, attitude, and practice were assessed by a questionnaire that comprised 43 items. Information relating to the socio-demographic characteristics and judo practice of the participants were also acquired. The levels among the surveyed judokas were low for knowledge (62; 78.5\%), attitude (49; 62.0\%), and practice (49; 62.0\%). The level of knowledge was significantly associated with attitude and practice for MR $\left(x^{2}=3.99 ; \mathrm{p}=0.04\right.$; Cramer's $\left.\mathrm{V}=0.22\right)$. The association between the levels of attitude and that of practice was non-significant $(\chi 2=0.29 ; \mathrm{p}=$ 0.59). The judokas of developing countries like those in southern Benin would benefit from specific training and participation in more competitions to improve their practice regarding MR and their sports performance.

Key Words: KAP survey, Judo, Muscular reinforcement, Developing country.

Corresponding Author:

Polycarpe Gouthon

E-mail: goupoly@yahoo.fr 


\section{INTRODUCTION}

Judo is a fighting sport created by Jigoro Kano Shihan in 1882 (1) created from the old martial arts (2). The philosophy developed by Kano articulates several fundamental principles, among which is the concept of non-resistance. This means not to oppose the force developed by the adversary, but to use it to overcome him. While respecting the spirit of the discipline, it is interesting to associate force and technique to ensure better execution of movement (3). At certain phases of a fight, such as the catch of kumi kata (guard), the exit from immobilization (toketa), and projections (nagewaza), muscular strength is essential.

Muscular reinforcement (MR) is the use of specific exercises to increase the capacity of the muscles to produce the various types of force (maximum, explosive, plyometric, etc.). It is, thus, not aberrant or contradictory to the spirit of judo. The virtues of MR and its importance in the training of the modern judoka has been recognized as a determining factor in performance at all levels of practice $(4,5)$. The fundamental principles which underlie MR are well-understood by trainers and athletes from developed countries. In these countries, exercise is integrated into training plans and preparation for competition to improve muscular capacity and performance (6).

In the current environment for judo in developing countries, typified by the Republic of Benin in West Africa, the ambition of the new brain trust is to improve the level of performance of practitioners even as the scarcity of competition is slowing the process down. Add to this the very low number of training sessions (average of two per week) to which judokas are subjected and such conditions do not allow adequate physical preparation and a fortiori implementation of an adequate plan for MR.

To improve the physical capacities of the judokas, it is necessary to draw up an inventory to determine why unsatisfactory judo results that have persisted such countries, particularly in Benin, for at least a decade and understand how the results relate to the low level of knowledge, attitude, and practice for MR. Such an inventory makes it easier to determine the strategies and training sessions to be implemented to support the ambitions of the Judo Federation. Despite their significant number of publications (7-10), very few present the realities of judo in developing countries, especially in African countries like the Republic of Benin. This study was undertaken to determine the level of knowledge, attitude, and practice among judokas in developing countries like Benin about MR and detect relationships between these factors among the judokas.

\section{MATERIALS AND METHODS}

This was a cross-sectional survey on the level of knowledge, attitude and practice (KAP) among judokas (athletes and trainers) in southern Benin. It was approved by the Executive Board of the Beninese Federation of Judo and received approval from the Sports Science Council of the University of Abomey-Calavi, which serves as the Committee on Ethics.

Participants. The target population was all judo athletes and trainers who practise in the largest two cities of southern Benin (Cotonou and Porto-Novo). A nonprobabilistic and exhaustive sample was constituted to carry out this study, so all 79 judokas who satisfied the inclusion criteria were recruited. The criteria were to be a judo athlete having earned at least a green belt or a trainer in a dojo and to hold a valid sporting license from the Beninese Federation of Judo for the 2012-2013 season. The target participants were informed of the objectives of the study and were guaranteed confidentiality and anonymity of the data collected. All participants signed written consent forms before participating in the study. 
Data Collection. The data was collected using a KAP questionnaire $(11,12)$ comprising 43 items divided into the following five dimensions: 1) sociodemographic characteristics (13 items); 2) history of judo practice (13 items); 3) knowledge of muscle resistance (13 items); 4) attitude (9 items); 5) MR practices (8 items). A pre-investigation carried out with 20 judokas who were not part of the study sample made it possible to test the sensitivity of the questionnaire. Seven questions were, thus, modified to make them more comprehensible to the target judokas. The values for Cronbach's $\alpha$ were $0.60,0.62$, and 0.66 for questions relating to knowledge, attitude and practice, respectively. These values were considered to be very close to the limit of $\alpha=0.70$ and the questionnaire was deemed reliable for use in this first survey related to MR.

Data-collection took place from 1to 15 June 2013. All surveyed judokas completed the questionnaires themselves in the presence of the investigator, except for three trainers who could not write. The questionnaires were distributed at training sites just before the sessions and were collected as soon as they were completed. Some questionnaires were left to the disposal of trainers in the dojos for judokas who were absent and were collected after they had been filled in.

Study Variables. The composite variables of knowledge, attitude, and practice relating to MR were examined. The variable of knowledge about $\mathrm{MR}$ was divided into four dimensions as follows: 1) definition of MR and the identification of the muscles addressed by MR; 2) reasons justifying the incorporation of MR into judo; 3) knowledge relating to the planning and implementation of an MR workout; and 4) knowledge relating to qualities and capacities that judokas must develop. The variable of attitude towards MR was divided into four dimensions as follows: 1) personal search for information relating to $\mathrm{MR} ; 2$ ) awareness of the importance of MR; 3) investment in MR; and 4) self-evaluation of personal practices regarding MR. The variable of practice related to $\mathrm{MR}$ was divided in three dimensions as follows: 1) planning MR; 2) muscular qualities and parts of the body that are targeted; and 3) qualifications and competence of staff supervising MR training.

The variables were made operational by the values assigned to each answer. For true-false questions, a value of 1 denoted a true response and 2 denoted a false response. For multiple-choice questions, the answer was regarded as correct when the judoka gave the right responses for at least $60 \%$ of items. The level was considered high for a dimension when $80 \%$ of the questions constituting that dimension were correct (13). The level was established as high for a variable when a surveyed judoka cumulated a high level of $80 \%$ for all dimensions included in the variable.

Statistical Analysis. The data was processed using SPSS (version 18) software. The results were presented as mean $(\mathrm{m}) \pm$ standard deviation (SD) for quantitative variables and as percentage (\%) for category variables. The $x^{2}$ test was used to assess the association between the different categories. Cramer's V was calculated to assess the degree of association between variables. The level of significance of the statistical tests was set at $\mathrm{p}<0.05$.

\section{RESULTS}

Socio-demographic characteristics and history of judo practice. This study was carried out with 79 judokas practising in 18 dojos in Cotonou and Porto-Novo and included 63 males (79.7\%) and 16 females (20.3\%). Overall, 73 (94.2\%) had attended at least secondary school and 46 (60.5\%) had more than five years of judo practice. There were 29 (37.2\%) black belts, 5 (6.4\%) chestnut belts and 44 (56.6\%) colour belts (Table 1$)$. 
Table 1: Socio-demographic and sporting practice characteristics of judokas.

\begin{tabular}{|c|c|}
\hline & Number (\%) \\
\hline \multicolumn{2}{|l|}{ Age $(n=76)$} \\
\hline $15-19$ years & $19(25.0)$ \\
\hline 20-35 years & 43 (56.6) \\
\hline 36 years and above & $14(18.4)$ \\
\hline \multicolumn{2}{|l|}{ Weight categories $(n=69)$} \\
\hline Light & $56(81.2)$ \\
\hline Middle weight & $13(18.8)$ \\
\hline \multicolumn{2}{|l|}{ Level $(n=78)$} \\
\hline Black belt & $29(37.2)$ \\
\hline Chestnut belt & $5(6.4)$ \\
\hline Colour belt & $44(56.4)$ \\
\hline \multicolumn{2}{|l|}{ Education $(n=77)$} \\
\hline Uneducated and primary school education & $4(5.2)$ \\
\hline Secondary school education & $27(35.1)$ \\
\hline Higher education & 46 (59.7) \\
\hline \multicolumn{2}{|l|}{ Seniority in practice $(n=76)$} \\
\hline More than 5 years & $46(60.5)$ \\
\hline Less than 5 years & 30 (39.5) \\
\hline \multicolumn{2}{|l|}{ Status $(n=79)$} \\
\hline Trainers & $17(21.5)$ \\
\hline Athletes & $62(78.5)$ \\
\hline
\end{tabular}

Weight divisions: (U60 kg, U48 kg; U63 kg; U66 kg,U73 kg); middle weight division: (U70 kg, U81 kg, U90 kg); colour belts: blue and green belts; $\mathrm{n}$ : sample size.

Levels of knowledge, attitude and practice regarding MR. The frequencies of the responses to questions are presented according to variable in Tables 2, 3, and 4. The levels of knowledge, attitude, and practice were weak in 62 (78.5\%), 49 $(62.0 \%)$ and $49(62.0 \%)$ of judokas, respectively (Table 5). There was no significant difference between the levels of trainers and those of the athletes ( $p>0.05)$.

Level of knowledge versus attitude and practice. Table 6 indicates that the $33.3 \%$ of judokas who showed a high level of knowledge and attitude with respect to MR were significantly more numerous than the $14.2 \%$ who had a high level of knowledge, but a low level of attitude or practice $(\mathrm{p}<$ 0.05 ). Table 7 shows that the proportion of judokas with a good level of both attitude and practice did not differ significantly from that of judokas who adopted a good attitude towards MR but had a low level of practice $(\mathrm{p}>0.05)$.

\section{DISCUSSION}

The objective of this study was to inventory the features of knowledge, attitude, and practice regarding MR among judokas from southern Benin to determine whether those who had a high level of knowledge also had a high level of attitude and practice. For Beninese judo practice, the results of the survey revealed that the levels are low in the majority of practitioners. They also showed that the level of knowledge positively influenced attitude and practice relating to MR. The level of the attitude was not associated with practice in these judokas. Rank in Judo, gender, and education also did not influence the levels of knowledge, attitude or practice. 
The results show that more than half (58.5\%) of participants had completed secondary school and a third (34.2\%) had attended university. The low level of knowledge and attitude can be primarily explained by the fact that, despite their level of education, the judokas were not wellinformed of the methods by which one can develop strength because the information was not available to them.

Table 2: Responses of judokas on level of knowledge regarding MR.

Questions related to the level of knowledge and the frequency of responses

\section{Definition of $M R$}

1. MR aims to:

Make muscle grow bigger 33 (42.3\%)

Making muscle stronger, faster, endure more 46 (57.7\%)

2. The muscles responsible for movements are

The smooth ones 34 (43.6\%)

The skeletal ones 44 (56.3\%)

3. The antagonist muscle is the one which

Is opposed to the movement $38(48.7 \%)$

Realizes the movement 40 (51.3\%)

4. A muscle can realize many types of contractions

Relaxatives 57 (73.1\%)

Other contractions (concentrics, eccentrics, etc.) 21 (26.9\%)

5. MR makes it possible to increase the strength and power of the contractions of

Smooth muscles 32 (41.0\%)

Skeletal and cardiac muscles 46 (59.0\%)

Usefulness of MR

6. Why must you realize $M R$ ?

To improve technical capacities 41 (52.6\%)

To improve one's strength and speed 37 (47.4\%)

7. Is MR practicable and useful for judokas at any age?

No 45 (57.0\%)

Yes 34 (43.0\%)

8. Do you think that MR is useful for success in the judo practice?

No $9(11.4 \%)$

Yes $70(88.6 \%)$

Planning of $\mathbf{M R}$

9. At what period of the sporting season can you realize MR?

Throughout the season or during the transition period 41 (52.6\%)

During other periods of the sporting season 37 (47.4\%)

10. $M R$ is realized in a

Fitness centre 56 (70.9\%)

Dojo 23 (29.1\%)

11. $M R$ is realized

With additional weights 71 (89.9\%)

Without additional weights 8 (10.1\%)

Qualities and capacities to be developed in judo

12. The physical qualities a judokas has to develop are

Doesn't know 25 (32.1\%)

Strength, speed, power, flexibility, aerobic endurance 53 (67.9\%)

13. Are there exercises which permit developing strength, speed, flexibility, motor coordination, power and aerobic endurance?

Doesn't know 29 (37.2\%)

Yes 49 (62.8\%)

MR: muscular reinforcement.

Gouthon, P. and et al. (2015). Ann Appl Sport Sci, 3(2): 11-22. 
Table 3: Responses of judokas related to the level of behaviour regarding MR.

Questions related to the level of behaviour and frequency of the responses

Search for information related to $M R$

1. Where have you sought for information about MR ?

Other persons 54 (68.4\%)

With the judo teacher, in specialized journals, on the Internet 25 (31.6\%)

2. Have you already discussed with other judokas about methods of MR development?

No 28 (35.4\%)

Yes51 (64.6\%)

Awareness of the importance of MR in judo

3. Are you available to improve your knowledge about MR?

No 4 (5.1\%)

Yes 75 (94.9\%)

4. Would you agree to realize MR all along your judo career?

No $19(24.1 \%)$

Yes 60 (75.9\%)

Dispositions to invest for MR practice

5. Are you ready to get materials for MR realization?

No $10(12.7 \%)$

Yes 69 (87.3\%)

6. Do you usually invest money for MR realization?

No 45 (57.0\%)

Yes 34 (43.0\%)

Appreciation of individual practices regarding $M R$

7. Do you think that you use appropriate methods of MR?

No 56 (70.9\%)

Yes 23 (29.1\%)

8. Would you agree to participate in additional sessions of MR to your usual weekly sessions of judo training?

No $14(17.7 \%)$

Yes 65 (82.3\%)

9. Are you ready to modify your MR methods and practices?

No $12(1.2 \%)$

Yes $67(84.8 \%)$

MR: muscular reinforcement.

The particularly low level of attitude can reasonably be explained by the ambitions of people who practise judo in Benin. Like practitioners from other countries (even in Africa), they do not seem to be ready to make the necessary sacrifice, in terms of resources (intellectual, temporal, material, financial) to reach the level of the international elite. The absence of assistant trainers and of equipment for muscular reinforcement in the dojos, even at the Federation level, contributes to the low level of practice regarding MR in the judokas surveyed.
It is known that good material conditions and organizational environment must be accompanied by the desire or need of sportsmen to improve their performances. Unfortunately, the national championship is held at irregular intervals and participation of Beninese judokas in competitions at the international level is low. It is difficult to expect athletes to be motivated to adopt good practices for strength development when there is no need felt. Defeat during national or international competitions could indeed make athletes more aware of the need 
to improve factors of performance such as muscle force, but Beninese judokas seldom have the opportunity to participate in such competitions. Consequently, most of them disagree with the recommendations for sportsmen to integrate MR into training sessions and preparation for competition (6).

In spite of their low level of knowledge about MR, most judokas were aware that it is useful to perform well. They also knew muscles in the different parts of the body that need to be reinforced; however, this is not enough. They must know the current most frequently-used methods and techniques for MR, such as plyometric (14) and performance in the special judo fitness test $(15,16)$, to improve sports performance in general. About two-thirds of the judokas who practice MR, show interest in the abdomen and lower and upper limbs, it is in accordance with the recommendations of Heller et al. (17) for practitioners of fighting sports.

Table 4: Responses of judokas related to the level of practices related regarding MR.

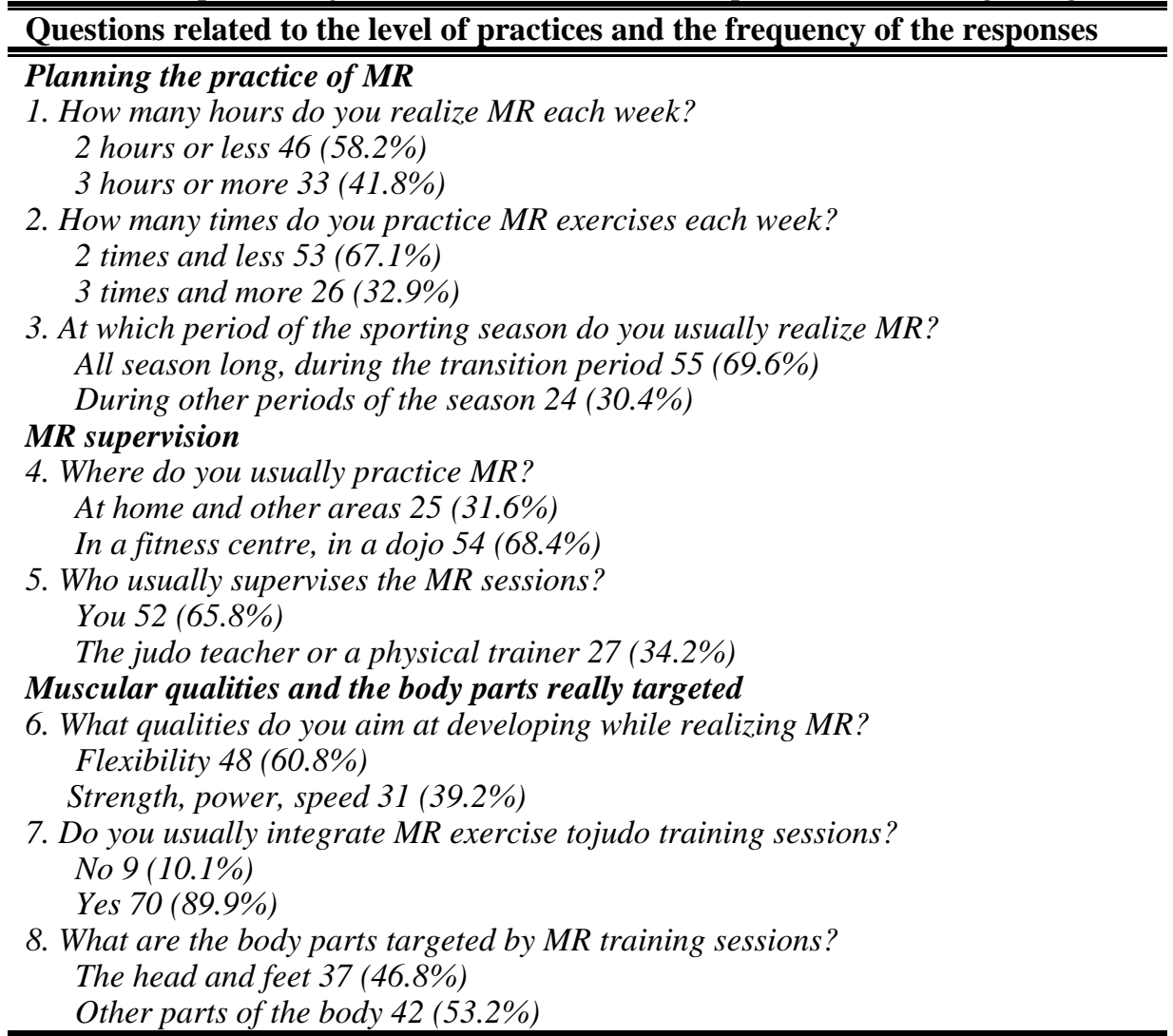

MR: muscular reinforcement.

Table 5: Level of knowledge, behaviour, and practices regarding MR among judokas.

\begin{tabular}{|c|c|c|c|}
\hline \multirow[b]{2}{*}{ Level } & \multicolumn{3}{|l|}{ Variables } \\
\hline & $\begin{array}{l}\text { Knowledge } \\
\text { Number (\%) }\end{array}$ & $\begin{array}{l}\text { Behaviour } \\
\text { Number (\%) }\end{array}$ & $\begin{array}{l}\text { Practices } \\
\text { Number (\%) }\end{array}$ \\
\hline High & $17(21.5)$ & $30(38.0)$ & $30(38.0)$ \\
\hline Low & $62(78.5)$ & $49(62.0)$ & $49(62.0)$ \\
\hline
\end{tabular}

MR: muscular reinforcement 
Table 6: Level of knowledge versus behaviour and practice regarding MR among judokas.

\begin{tabular}{lcccccc}
\cline { 3 - 5 } & \multicolumn{2}{c}{ Level of knowledge } & & & \\
\cline { 3 - 6 } & & $\begin{array}{c}\text { High } \\
\text { Number (\%) }\end{array}$ & $\begin{array}{c}\text { Low } \\
\text { Number (\%) }\end{array}$ & $\chi^{2}$ & p & Cramer's V \\
\hline \hline \multirow{2}{*}{ Level of behaviour } & High & $10(33.3)$ & $20(66.6)$ & & & \\
& Low & $7(14.2)$ & $42(85.7)$ & & & \\
& High & $10(33.3)$ & $20(66.6)$ & & & \\
Level of practices & Low & $7(14.2)$ & $42(85.7)$ & 3.99 & $0.04^{*}$ & 0.22 \\
\hline \hline
\end{tabular}

MR : muscular reinforcement; *significant association at $\mathrm{p}<0.05$.

Table 7: Level of behaviour versus practice regarding MR among judokas.

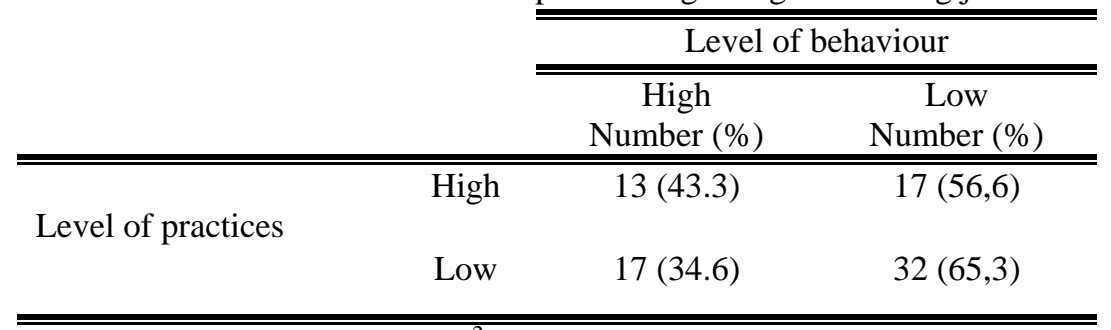

MR: muscular reinforcement; $\chi^{2}=0.297 ; \mathrm{p}=0.59$.

The positive association between the level of knowledge and attitude highlights the fact that knowledge is the basis of attitude. Knowledge is what individuals know; it is related to culture $(18,19)$ and makes it possible to organize attitude. Attitude relates to perceptions and the difficulty or ability of individuals to understand the phenomenon (20), which will determine their tendencies and dedication to adopt practices. A study relating to the relationship between knowledge, attitude, beliefs and behaviour towards AIDS in Ilede-France highlighted the significant association between knowledge and attitude (21). Contrary to the results of the current survey, that study revealed an association influenced by the educational level of the judokas. The example of the study on AIDS illustrates that educational level appears to be associated with attitude in KAP surveys carried out in fields other than that of sports.

The level of practice noted in the results was only $22 \%$ that of knowledge, as shown by Cramer's V $=0.22$. The degree of association observed cannot be compared with that of other studies, such as that one carried out on hydration practices among young handball players in Benin (22). Those authors compared handball players and nonathletes and noted that the players had 44.8 times more opportunity to adopt good practices. The authors interpreted this result, which seems to contrast with that of the current study, as being associated with the instructions of trainers, who incite players to hydrate themselves regularly during training sessions. The hydration practices of the 
players, thus, were partly determined by an external intervention, i.e., that of their trainers. The judokas of the current study do not seem to be well-supervised regarding MR because the level of the trainers is nearly as low as that of the athletes. It is evident that trainers require specific training programmes to improve their own levels so as to influence that of the athletes.

The level of attitude was not associated with that of practice; in other words, not many of those who adopt a good attitude towards MR had good practices for MR. This is contrary to initial expectations, because implementation of the KAP study was founded on the postulate that a good level of knowledge induces good attitudes which in turn support adoption of good practices. The data collected in the current study indicate that these hypothetical relations are not always verified and that there can be a difference between good attitude and good practice. Good attitude, which accounts for a positive provision and practice, often comprises intermediate factors like material conditions, infrastructure, and institutional framework as well as socio-cultural context and availability.

A study on the influence of knowledge of and attitude toward nicotinism showed a positive association between attitude and practice (23). This association, because of the predisposition of individuals to nicotinism, did not directly affect their investment or a particular effort. In the case of MR, judokas must invest in themselves, perhaps sacrifice their work or rest times, and agree to make the necessary effort to satisfy the methodological requirements of MR training to reach satisfactory results.

\section{CONCLUSION}

This KAP survey is one of the first of its kind on muscular reinforcement among sportsmen in developing countries, especially in sub-Saharan Africa. It has made it possible to draw up an inventory of fixtures on the environment of judo in Benin. The data collected revealed that the majority of judokas (trainers and athletes) surveyed had a low level of knowledge, attitude, practice regarding MR and most of those who adopted good attitudes had a low level of practice. It appears that the initial ideas underlying implementation of this research are partly confirmed. The first obstacle to effective practice of MR is primarily the low level of knowledge and attitude; however, the material conditions of practice (competence of teachers, sporting equipment, system of competition) constitute the real obstacles.

The main limitations of this study are not different from those for any cross-sectional study which is based on static data and does not account for the evolution of the study subjects over a given period. Another limitation is that associated with KAP surveys that are supported by relations that are assumed theoretically to exist between the knowledge of those surveyed, their attitudes or beliefs, and their practices regarding the studied phenomenon.

\section{APPLICABLE REMARKS}

- It is necessary for leaders (Ministries of Sport, Federations of Judo, and structures like the National Olympic and Sporting Committee) to combine their efforts to initiate a major programme of specific training for trainers and, create fitness centres for athletes in developing countries.

- The judokas from developing countries should also participate in more competitions to better comprehend the usefulness of the MR and have more opportunities to appreciate their abilities when use their specific strengths during the shaïs in competition. 


\section{ACKNOWLEDGEMENTS}

The authors sincerely thank the people in charge of Vita Form fitness and cardiovascular centre in Porto-Novo for their technical support during data collection and processing. We particularly thank the members of the Beninese Federation of Judo, the coaches of the judo clubs, and all the judokas for their participation in this study.

\section{REFFRENCES}

1. Pocecco E, Burtscher M, editors. Physiological profiles of judo athletes. MLADÍ EVROPANÉ VE VĚDĚ 2005; 2006; Praha.

2. Woodward TW. A review of the effects of martial arts practice on health. WMJ : official publication of the State Medical Society of Wisconsin. 2009;108(1):40-3.

3. Manno R. Les bases de l'entraînement sportif: Ed. Revue EP. S; 1992.

4. Cronin J, Sleivert G. Challenges in understanding the influence of maximal power training on improving athletic performance. Sports medicine (Auckland, NZ). 2005;35(3):213-34.

5. Guincestre JY, Sesboue B, Cavelier V, Hulet C. Principes, usages, mésusages et risques du renforcement musculaire. Journal de Traumatologie du Sport. 2005;22(4):236-42.

6. Fleck SJ, Kraemer WJ. Designing Resistance Training Programs. 3rd ed: Human Kinetics; 2004. 377 p.

7. Blais L, Trilles F. The progress achieved by judokas after strength training with a judo-specific machine. Journal of sports science \& medicine. 2006;5(Cssi):132-5.

8. Krstulović S. Judo training is more effective in fitness development than recreational sports in 7 year old girls. Facta Universitatis Series: physical dducation and sport. 2010;8:71-9.

9. Krstulović S. Predictors of judo performance in male athletes. Homo Sporticus. 2012;14(2):5-10.

10. Viveiros L, Costa EC, Moreira A, Nakamura FY, Aoki MS. Training load monitoring in judo: comparison between the training load intensity planned by the coach and the intensity experienced by the athlete. Revista Brasileira de Medicina do Esporte. 2011;17(4):266-9.

11. Médecins du Monde. collecte de données Méthodes quantitatives l'exemple des enquêtes CAP (connaissances, attitudes \& $\quad$ pratiques) $2011 \quad\left[\begin{array}{lllll}2013 & 15 & \text { June }\end{array}\right.$ Available from: http://www.medecinsdumonde.org/Publications/Guides-a-l-usage-des-professionnels-de-l-humanitaire/Collectede-donnees-methodes-quantitatives-l-exemple-des-enquetes-CAP-connaissances-attitudes-pratiques.

12. World Health Organization. A guide to developing knowledge, attitude and practice surveys Geneva, WHO2008.

13. Varkevisser CM, Pathmanathan I, Brownlee AT. Designing and conducting health systems research projects: IDRC; 1993.

14. Chu DA. Plyometric Training for Youth 2004 [2013 16 June $]$. Available from: http://www.donchu.com/articles/article7/.

15. Franchini E, Sterkowicz S, Szmatlan-Gabrys U, Gabrys T, Garnys M. Energy system contributions to the special judo fitness test. International journal of sports physiology and performance. 2011;6(3):334-43.

16. Miarka B, Del Vecchio FB, Franchini E. Acute effects and postactivation potentiation in the Special Judo Fitness Test. Journal of strength and conditioning research / National Strength \& Conditioning Association. 2011;25(2):427-31.

17. Heller J, Peric T, Dlouha R, Kohlikova E, Melichna J, Novakova H. Physiological profiles of male and female taekwon-do (ITF) black belts. Journal of sports sciences. 1998;16(3):243-9.

18. Handicap International. Guide à l’intention des chefs de projet: Connaissances attitudes pratiques 2009 [2013 6 December]. Available from: http://www.handicap-international.org.uk/.../kap.risk.educ.

19. Hausmann-Muela S, Ribera JM, Nyamongo IK. Health-Seeking Behaviour and the health system response. DCPP Working Paper N 142003 [2013 6 December]. Available from: www.dcp2.org/file/29/wp14.pdf.

20. Duteau JE, Christelle M. Rapport final d'enquête sur les connaissances, attitudes et pratiques : Enquête sur les connaissances, attitudes et pratiques des professeurs du cycle fondamental 1 de la région goâvienne quant à la gestion des risques et des désastres naturels ABS2012 [2013 5 May]. Available from: http://www.preventionweb.net. 
21. ORS-IF. Connaissances attitudes, croyances et comportements face au VIH/SIDA en Ile-de-France en 20102011 [2012 26 August]. Available from: http://www.ors-idf.org/dmdocuments/rapport_KABP_2011.

22. Bio Nigan I, Falola J-M, Gouthon P, Akplogan B, Djékété M, Bio Nigan RY-T, et al. Current knowledge, attitudes and practices regarding hydration of student handball players in the South-eastern region (Ouemeplateau) of the Republic of Benin. Herald Journal of Education and General Studies. 2013;2(2):072 - 6.

23. Lin Y-S, Wu D-M, Lai H-R, Shi Z-P, Chu N-F. Influence of Knowledge and Attitudes on Smoking Habits Among Young Military Conscripts in Taiwan. Journal of the Chinese Medical Association. 2010;73(8):411-8. 
تازههاى علوم كاربردى ورزش

دوره سوم، شماره دوم

مقاله اصيل

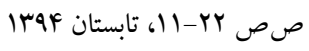

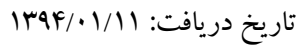

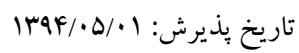

\section{دانش،، نَرش و شيوههاى مرتبط با تقويت ماهيجٌه ميان جودوكاران كثنورهاى در حال توسعه: مورد مطالعه جممورى بنين}

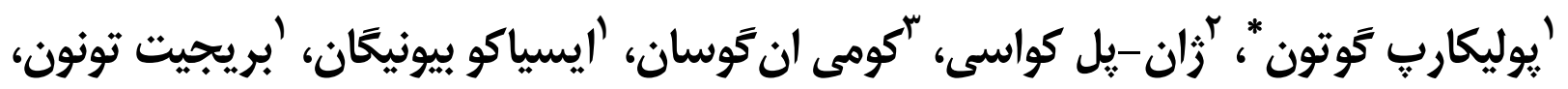

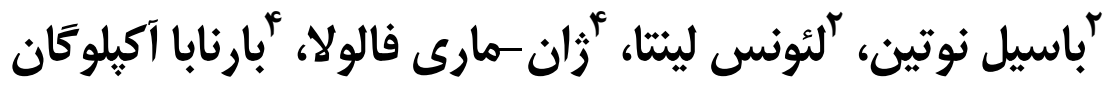

ا. استاديار، آزمايشگاه PSA و موتريسيتى، يزوهشگاه ملى جوانان، تربيتبدنى و ورزش (INJEPS)، دانشكاه آبومى-كالاوى، يورتو-نوو، جمهورى بنين. r. كارشناسى ارشد، آزمايشخاه PSA و موتريسيتى، يزوهشكاه ملى جوانان، تربيتبدنى و ورزش (INJEPS)، دانشخاه آبومى-كالاوى، يورتونوو، جمهورى بنين. ז. استاديار، أزمايشگاه بيولوزى، موتريسيتى، اجراى ورزشى، يزشكى ورزشى و ييشخيرى، يزوهشگاه ملى جوانان، تربيتبدنى و ورزش، عبيدجان، جمهورى كوته دِ ايووير. f. استاديار، آزمايشًاه بيومكانيك و اجرا (LABIOP)، يزوهشكاه ملى جوانان، تربيتبدنى و ورزش (INJEPS)، دانشخاه آبومى-كالاوى، يورتو-نوو، جمهورى بنين.

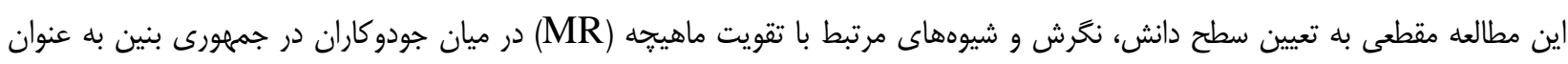

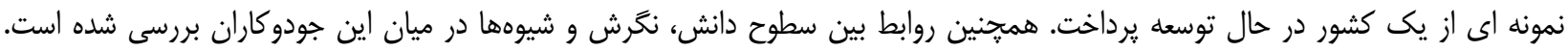

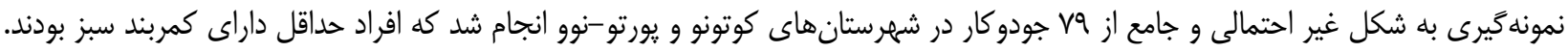

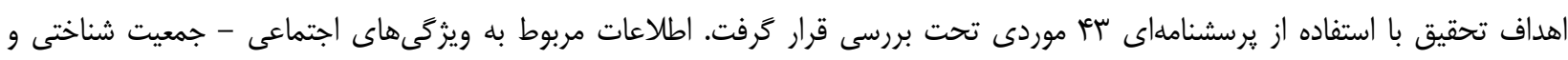

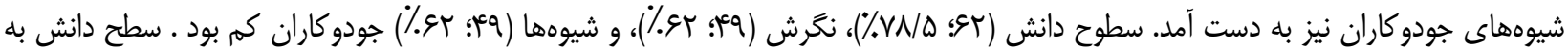

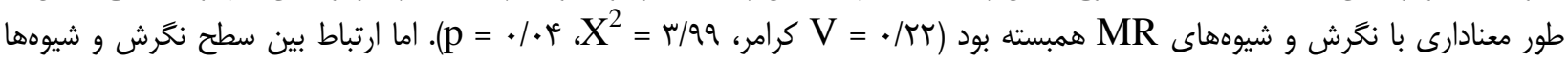

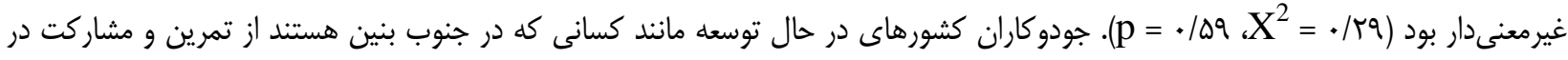

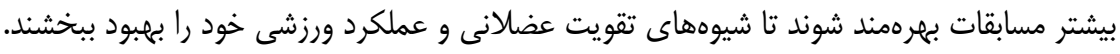
وازگًان كليدى: دانش، نكَرش، شيوه، جودو، تقويت عضلانى، كشورهاى در حال توسعه.

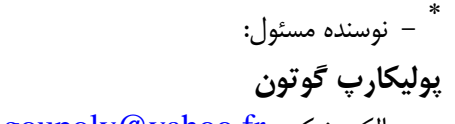

gست الكترونيك: ويكارن ونون goupoly@yahoo.fr 